\title{
A new fish, Peristedion nesium (Scorpaeniformes: Peristediidae) from Isla del Coco, Costa Rica
}

\author{
William A. Bussing \\ Escuela de Biología \& Centro de Investigaciones en Ciencias del Mar y Limnología (CIMAR), Universidad de Costa \\ Rica, San José, Costa Rica; william.bussing@ucr.ac.cr
}

\author{
Received 21-IX-2009. C Corrected 03-V-2010. Accepted 04-VI-2010.
}

\begin{abstract}
Several expeditions in recent years to Isla del Coco have increased the total number of species of fishes known from the island. Several of these species have been described as new endemics (Bussing 1983, 1990, 1991a, 1991b, 1997). During the 1972 R/V Searcher Expedition to Costa Rica several trawl collections were made around Isla del Coco. At five localities in depths between 110 and 180m, 86 specimens of a new species of Peristedion were taken and are described herein. A key to the four species of Eastern Pacific Peristedion is included. Rev. Biol. Trop. 58 (4): 1149-1156. Epub 2010 December 01.
\end{abstract}

Key words: Peristedion, new island species, Isla del Coco, Costa Rica, Galápagos.

The armored searobins (Peristediidae) are usually found in waters greater than $100 \mathrm{~m}$. Their body is encased in four rows of spinous scutes on each side of the body and the wide snout is extended by a pair of flattened bony extensions. The genus Peristedion, although speciose in the Western Atlantic, has only three previously known representatives along the Eastern Pacific coastline: P. crustosum Garman, P. barbiger Garman and $P$. paucibarbiger Castro-Aguirre \& García-Domínguez, 1984. Another species, P. ecuadorense Teague, 1961, was incorrectly recorded from the eastern Pacific, although Miller (1967) has indicated that the correct locality for the type series is off Charleston, South Carolina in the Western Atlantic.

\section{MATERIALS AND METHODS}

Specimens of the new species were collected by $30 \mathrm{ft}$. trawl during the $1972 \mathrm{R} / \mathrm{V}$ Searcher Expedition. Counts and measurements follow
Teague (1961) and especially the anatomical characters and terminology of Miller (1967). All body proportions are in percent of standard length (SL). Vertebral numbers were determined from digital and photographic radiographs. Institutional acronyms follow Leviton et al. 1985.

\section{RESULTS}

Peristedion nesium, new species

Figures 1-4, Tables 1, 2.

Holotype: LACM 32265.003, $117.9 \mathrm{~mm}$ $\mathrm{SL}$, collected $2.4 \mathrm{~km}$ north of Isla Iglesias $\left(05^{\circ} 34^{\prime} 38^{\prime \prime} \mathrm{N} ; 8^{\circ} 033^{\prime} 55^{\prime \prime} \mathrm{W}\right)$ Isla del Coco, Costa Rica. Collected with 30' trawl, depth 183m, April 3, 1972 by R. Lavenberg and W. Bussing aboard the R/V Searcher (S-522).

Paratypes: Material collected off Isla del Coco by R. Lavenberg and W. Bussing aboard R/V Searcher: LACM 32269.007 and 32269.008 


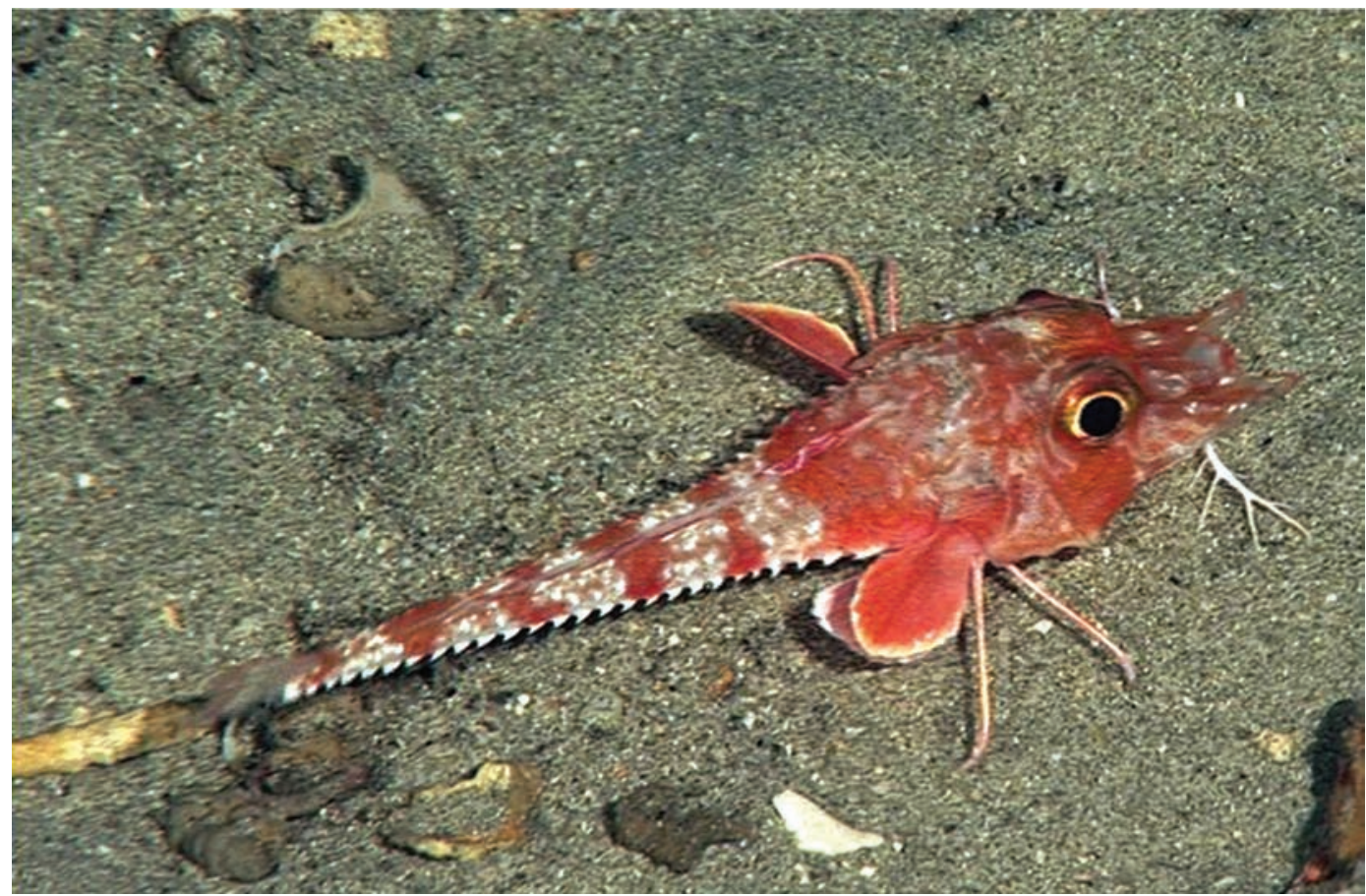

Fig. 1. Photograph of Peristedion nesium, n. sp. taken from a submersible at Isla del Coco, Costa Rica by Avi Klapfer. Depth not recorded.

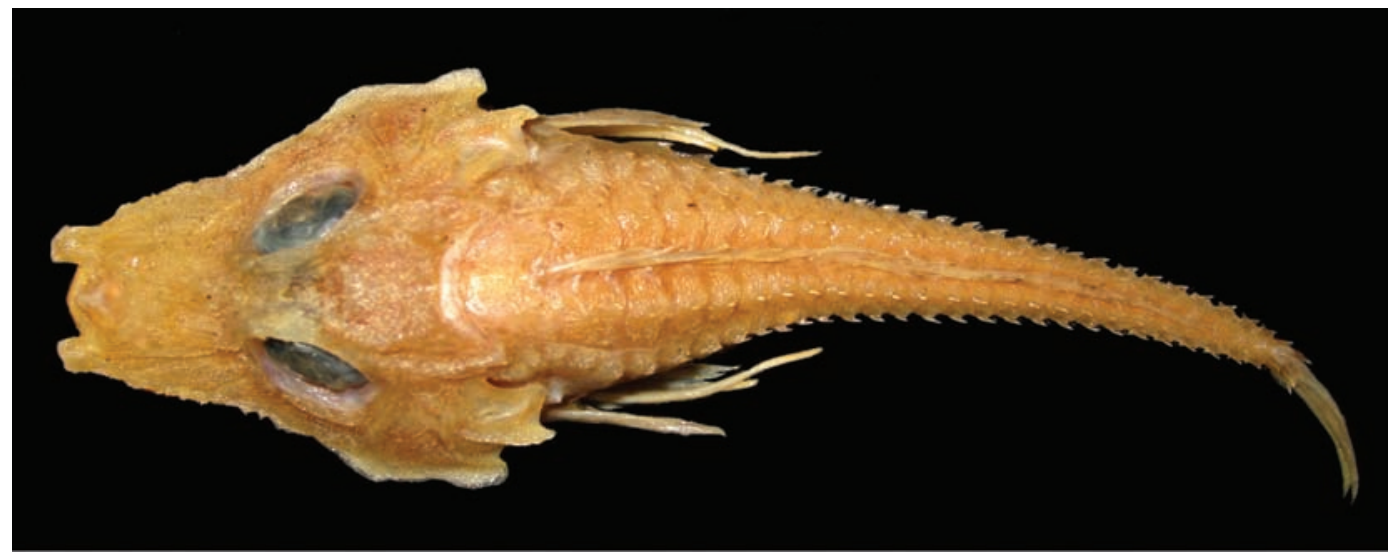

Fig. 2. Holotype of Peristedion nesium, n. sp., LACM 32265.003, 117.9mm from Isla del Coco, Costa Rica. Photo by R. Feeney. 


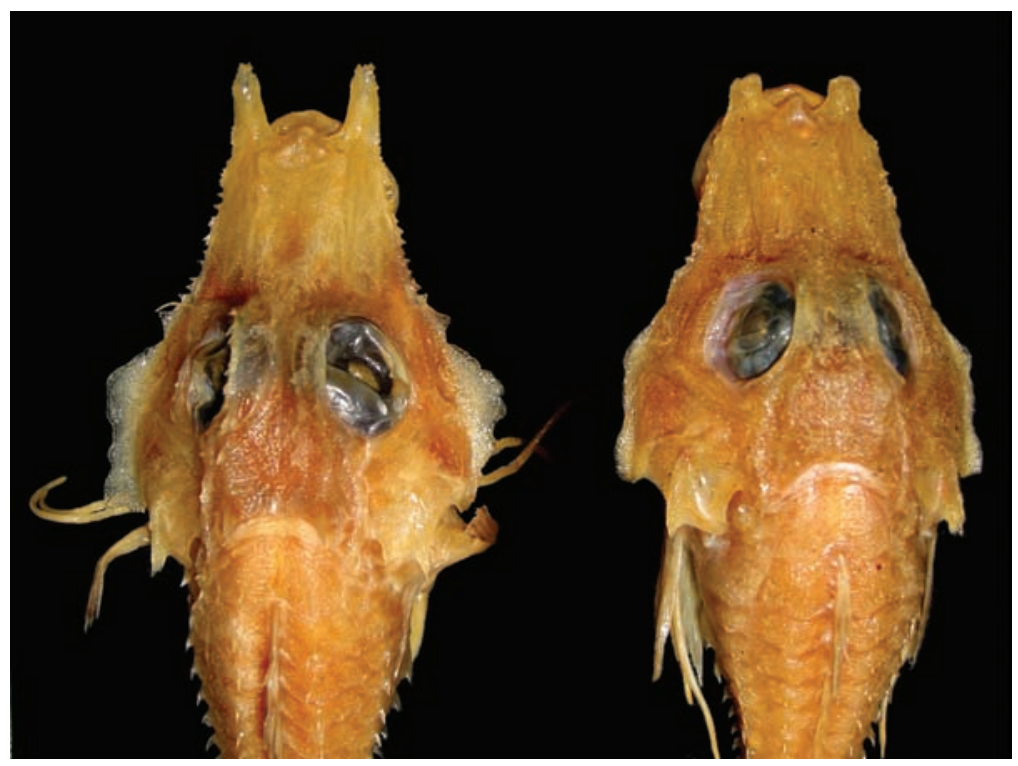

Fig. 3. Dorsal view of heads of Peristedion crustosum, LACM 20838, from Islas Galápagos (left side); holotype of Peristedion nesium, n. sp. from Isla del Coco (right side). Photo by R. Feeney.

TABLE 1

Proportional measurements in percent of standard length for holotype and paratypes of Peristedion nesium, n. sp. and one specimen of $\mathrm{P}$. crustosum

\begin{tabular}{|c|c|c|c|}
\hline Body measurements & 20 paratypes* & Holotype & Galápagos crustosum \\
\hline Standard length (mm) & $95.1-117.6$ & 117.9 & 127.8 \\
\hline Head length & $35.6-40.3$ & 46.3 & 36.7 \\
\hline Body depth at first dorsal spine & $18.1-22.6$ & 21.5 & 20.9 \\
\hline Body depth at anal-fin origin & $9.5-11.9$ & 10.1 & 11.7 \\
\hline Body width at pectoral-fin origin & $16.7-23.8$ & 23.7 & 23.4 \\
\hline Greatest head width & $29.0-36.5$ & 32.5 & 40.5 \\
\hline Length of joined pectoral-fin rays & $17.0-22.3$ & 16.8 & 13.2 \\
\hline Length of first free pectoral-fin ray & $17.2-26.1$ & 26.1 & 18.6 \\
\hline Length of second free pectoral-fin ray & $15.8-26.7$ & 17.6 & 22.1 \\
\hline Length of pelvic fin & $17.6-22.0$ & 20.6 & 18.5 \\
\hline
\end{tabular}

(S-526), 2.7km SSE off Cabo Dampier; collected with 30' trawl, depth 120m, April 3, 1972; $05^{\circ} 28^{\prime} 30^{\prime \prime} \mathrm{N} ; 87^{\circ} 04^{\prime} 00^{\prime \prime} \mathrm{W} ; 41$ specimens (51.5-116mm SL). LACM 32281.001 (S-541), $1.9 \mathrm{~km} \mathrm{~N}$ of Isla Iglesias; collected with $15^{\text {' }}$ trawl, depth $128 \mathrm{~m}$, April 5, 1972; 05 $34^{\prime} 21^{\prime \prime}$ $\mathrm{N} ; 8^{\circ} 03$ '48" W; 1 specimen $(72.5 \mathrm{~mm} \mathrm{SL})$. UCR 720.007 (S-520), 1.3km NNW of Punta Gissler; collected with 30 ' trawl, depth 109m,
April 3, 1972; 05³3'32" N; 8704'44” W; 18 specimens (74.5-117.5mm SL). CAS 228407, same data as UCR 720.007, 6 specimens (83.5$98.2 \mathrm{~mm} \mathrm{SL}$ ). UCR 721.008 (S-521), $2.6 \mathrm{~km}$ WNW Punta Gissler; collected with 30' trawl, depth 137-146m, April 3, 1972; 11 specimens $(77-107 \mathrm{~mm} \mathrm{SL})$. Other material: UCR 2272.004, Isla del Coco; collected with tangle net, April 8, 1992; 2 specimens (86-108mm 

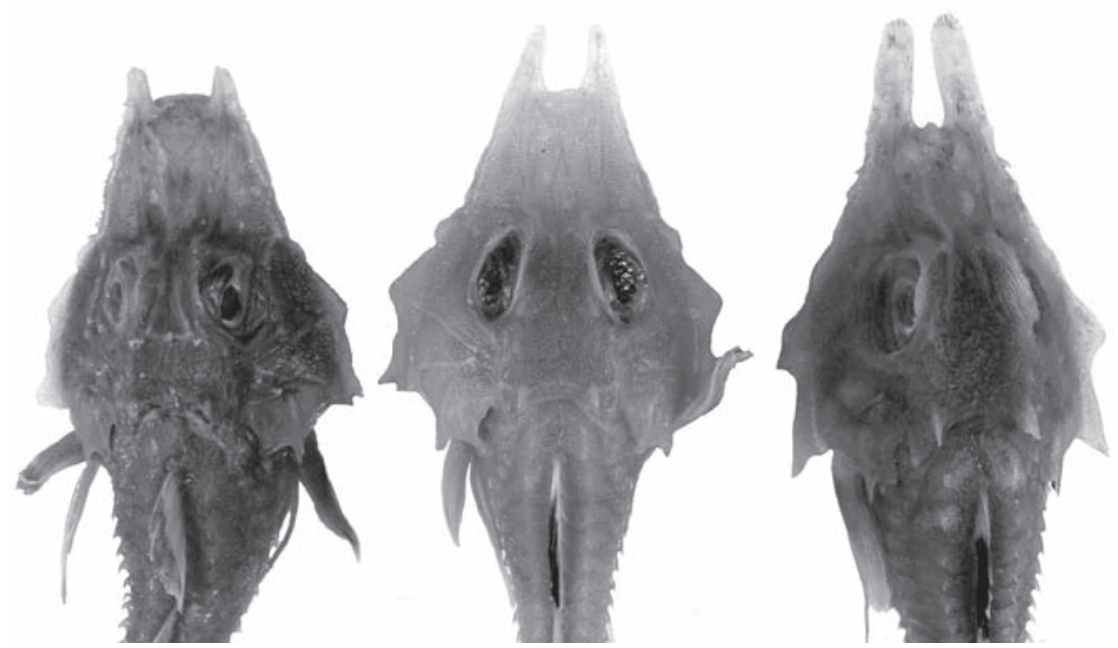

Fig. 4. Dorsal view of head of three species of Eastern Pacific Peristedion from Costa Rica. left, P. nesium, n. sp. UCR 720.007, 105.6mm; middle, P. crustosum, UCR 501.001, 108.4mm; right, P. barbiger, UCR 489.001, 107.5mm.

TABLE 2

Proportional measurements in percent of head length for holotype and paratypes of Peristedion nesium, n. sp. and one specimen of $\mathrm{P}$. crustosum

Body measurements

Filamentous barbel length

Lip barbel length

Chin barbel length

Snout length

Snout width

Orbital length

Orbital depth

Interorbital width

Rostral exsertion length

Width between rostral exsertions

Greatest width of rostral exsertion base

Width of rostral exsertion at middle

Width between tips of rostral exsertions

Distance between parietal spines

Nape length

\section{Paratypes*}

31.8-44.2

7.9-13.7

13.3-22.7

41.5-45.7

33.4-40.1

23.8-29.8

21.4-26.4

13.7-18.8

12.1-19.0

7.8-15.2

10.5-14.1

6.1-7.9

20.0-27.5

$17.6-22.3$

15.7-20.2

Holotype
37.6
11.9
19.0
44.9
39.3
25.5
21.8
15.3
10.6
10.2
10.4
8.0
21.4
20.1
17.5

Galápagos crustosum

40.1

14.0

12.4

47.1

38.6

24.7

23.9

18.3

19.2

13.0

12.8

6.6

27.3

21.1

18.1

*UCR 720.007 (10 I. del Coco paratypes); LACM 32269.008 (10 I. del Coco paratypes); LACM 20838 (I. Galápagos).

SL). UCR 2273.001, Isla del Coco; collected with tangle net, April 2, 1992; 1 specimen (112mm SL).

Diagnosis: A species of Peristedion with very short (12.1-18.2\% in head length) and widely spaced rostral exsertions; pericranial rim terminating in a right-angled flange; rostral and nasal spines present from juveniles to adults; gill rakers 5-9+27-31, total 33-40 and length of filamentous barbel $31.8-44.2 \%$ of head length. 
Description: Tables 1 and 2 give morphometrics of the holotype, 20 adult paratypes and one specimen from the Galápagos of $P$. crustosum.

Holotype: Standard length $117.9 \mathrm{~mm}$. Dorsal fin rays VII, 17. Anal fin rays 16. Pectoral fin rays $9+2$ free rays. Pelvic fin rays I-5. Lip barbels $5 / 2: 5 / 2$; chin barbels $12 / 5: 11 / 5$. Gill rakers on first branchial arch $6+27=33$. Serrated ridge on mandible 1. Vertebrae 31. Scutes: dorsal series 25; superomedian series 30 , last 7 with bicuspid spines; inferomedian series 24 ; ventral series 20; caudal series $2+1+2$. Additional measurements (in percentage of head length): mandibular ridge length 6.9 ; mandibular ridge width $1.9 ; 1$ st ventral scute length $24.0 ; 1$ st ventral scute width 13.0; 2nd ventral scute length 21.2; 2nd ventral scute width 12.1 .

Paratypes: Dorsal fins VI-VIII, 16-18 (modally VIII, 17); anal 16-18 (modally 17); pectoral 2+9-11, (modally 11); pelvic I-5. Gillrakers on first branchial arch 5-9+27-31, total 33-40 (modally $8+29$, total 36 ). Vertebrae 31-33. Lip barbels 4-6/2 (modally 5/2). Chin barbels 10-15/5 (modally 12/5). Filamentous barbel short, rarely extending beyond middle of eye; filaments along barbel variable in length, occasionally longer than $50 \%$ length of entire filamentous barbel. Sensory pores on underside of rostral exsertions four: anterior three rounded, fourth pore elongated and considerably posterior to others.

Head spines and serrations: Spination is stronger in larger specimens; description of adult specimens of approximately $100 \mathrm{~mm}$ SL follow. Lateral ethmoid and mesethmoid spines are absent. Both rostral and nasal spines are well-developed, retrorse and elevated. Four or 5 spines and smaller serrations on the $2^{\text {nd }}$ infraorbital of the perifacial rim, anteriormost spine largest and elevated or lateral. Three or 4 preocular spines strongly retrorse; supraocular and postocular spines rounded, less developed. Frontal I spine undeveloped, a tubercle or low spine. Frontal II spine very small. Parietal spine a low, rounded tubercle. Opercular spine well developed, pungent. Fourth infraorbital ridge finely serrate. Two or 3 nuchal spines, sharp, retrorse, elevated. Two or 3 spines on adjacent $1^{\text {st }}$ dorsal scute.

Scutes: Dorsal series 25-26 scutes (modally 25), with robust spines preceded by minute serrations; size of spines decreasing posteriorly and more depressed. Superomedian total series 28-32 scutes (modally 30), first 4 scutes in arch with minute serrations only, succeeding scutes with large spines with anterior serrations; last 6 to 10 spines (modally 7 or 8 ) bicuspid, the last sometimes unicuspid. Inferomedian series 22-24 scutes (modally 23); all spines well developed, with anterior serrations, decreasing in size and flattening posteriorly. Ventral series 20 or 21 scutes (modally 20) all with minute spines, $1^{\text {st }}$ two very depressed or slightly raised tubercles; last scute at posterior anal-fin ray with flat spine or serrated tubercle. Caudal series consisting of two ventral, two dorsal and one lateral scute all with well-developed spines; lateral spine especially long and slender.

\section{A key to Eastern Pacific Peristedion}

1a. Head narrow; perifacial rim narrow and terminating in a retrorse spine; rostral and nasal spines

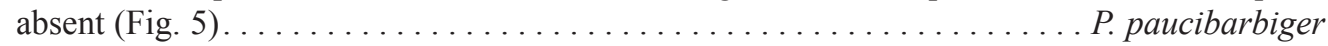

1b. Head and perifacial rim broad; rostral spines present $\ldots \ldots \ldots \ldots \ldots \ldots \ldots \ldots \ldots \ldots$

2a. Perifacial rim terminating in acute-angled spine; rostral exsertions wider than interspace, often convergent; nasal spines weak or absent; chin and lip barbels prominent; filamentous barbel short, rarely reaching to eye (Fig. 4) $\ldots \ldots \ldots \ldots \ldots \ldots \ldots \ldots \ldots \ldots \ldots \ldots$ barbiger

2b. Perifacial rim terminating in a right-angled or rounded flange; rostral exsertions narrow, widely spaced; nasal spines present; chin and lip barbels less bushy; filamentous barbel long, reaching

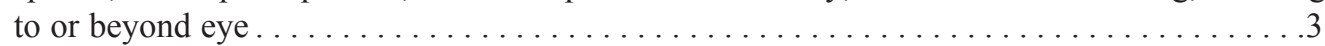


3a. Rostral exsertions longer than pupil diameter (21.1-25.8\% of head length); total gill rakers on first arch 27-29; length of filamentous barbel 61.5-69.4\% of head length (Fig. 4)

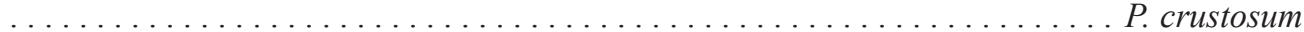

3b. Rostral exsertions very short, less than pupil diameter (12.1-18.2\% of head length); total gill rakers on first arch 33-40; length of filamentous barbel 31.8-44.2\% of head length (Fig. 4)

P. nesium

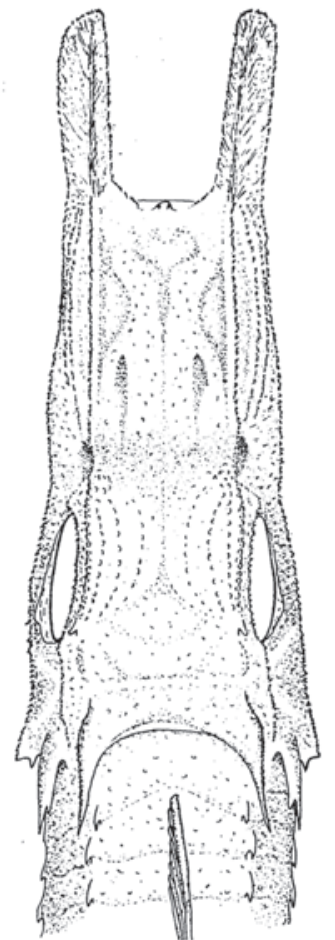

Fig. 5. Holotype of Peristedion paucibarbiger, dorsal view of head (from Castro-Aguirre \& García-Domínguez 1984).

\section{DISCUSSION}

Peristedion nesium n. sp. is apparently an island derivative of $P$. crustosum. Trenchant differences between the two species are shown in the key to species. Differences in coloration and head serration also exist between these two species. Adult P. crustosum, as well as P. barbiger from Costa Rica, have a jet black blotch on the upper half of the first five dorsalfin spines; juvenile crustosum (70mm SL) also have a black dorsal-fin blotch as well as a black upper half of the pectoral fin. The upper half of the spinous dorsal of nesium is dusky or unmarked; a $112 \mathrm{~mm}$ SL specimen has a pale dusky first dorsal fin and a black pectoral fin. Garman (1899) described crustosum and barbiger from off the mainland of Panama/ Colombia as red in life with a black upper spinous dorsal fin, although the young specimen of crustosum figured has only a dusky dorsal fin. The Garman figure of $P$. crustosum is very similar to a remarkable photograph of a living specimen of Peristedion taken from the submersible Johnson Sea-link on a seamount off the Galápagos (Richards \& McCosker 1998). The head is red, the upper body has four broad vertical red bars; the pectoral fins are bright red and the spinous dorsal fin is red with a white margin, and without a black blotch. A photograph of $P$. nesium taken by Avi Klapfer at Isla del Coco (Fig. 1) is very similar, with irregular red bars crossing the body, an anterior wide bar below the dorsal fin followed by five narrower irregular bars; dorsal and pectoral fins bright red with white margins; the head is red with a paler nape.

Differences in head spination between these similar species are most evident in large specimens. Frontal I and II spines and parietal spines in crustosum are sharp and elevated whereas these spines are small or reduced to tubercles in nesium. Contrarily nesium has three sharp elevated retrose nuchal spines compared to small single spines or tubercles in crustosum.

Some island species are shared between Isla del Coco and the Galápagos (eg. Elacatinus nesiotes Bussing, 1990; Dialommus fuscus Gilbert, 1891; Labrisomus dendriticus (Reid, 1935); Odontoscion eurymesops (Heller \& Snodgrass, 
1903); Mycteroperca olfax (Jeynyns, 1842) and thus it was of interest to compare the new species with another deep-water Peristedion from the Galápagos archipelago. Grove and Lavenberg (1997) described a Galápagos specimen (LACM 20838) of Peristedion crustosum (Fig. 3) and obtained data on two CAS (56256, 54561) specimens. These three specimens look like typical mainland specimens, but differ in their short filamentous barbels (38.2-40.2\% of head length) a characteristic which they share with $P$. nesium.

Also Figure 3 shows the very spinous $2^{\text {nd }}$ infraorbital rim on the LACM specimen that is different from any of the mainland specimens of P. crustosum that I have examined. Richards \& McCosker (ibid.) identified four additional specimens of Peristedion from the Galápagos during the Johnson Sea-Link cruise. On the basis of comparison with type material of the other two Eastern Pacific mainland species, they concluded the species to be $P$. crustosum. Clearly the Galápagos population of Peristedion retains the very characteristic long, slender rostral extensions of mainland P. crustosum, although through isolation has developed minor differences and in spite of their pelagic larvae, have maintained a separate population from the Isla del Coco P. nesium.

The species $P$. paucibarbiger was based on a single juvenile (70mm SL) specimen taken at a depth of $60 \mathrm{~m}$ en Bahía de La Paz, Baja California (Castro-Aguirre \& GarcíaDomínguez 1984). The authors compared this unique specimen with specimens of $P$. gracile Goode \& Bean (1895) (and P. taeniopterum Fowler 1952 which=gracile) a Western Atlantic Peristedion that shares the characteristics of a retrorse spine on a very narrow perifacial rim and the lack of rostral and nasal spines. Miller \& Richards (2002) included two other species in their narrow-headed "Peristedion gracile species group" from the Western Atlantic: P. imberbe Poey, 1861 and P. n. sp. " $\mathrm{t}$ ". In its original description, $P$. paucibarbiger was not compared with the two other Peristedion species from the Eastern Pacific mainland, P. barbiger and P. crustosum. Both juvenile
P. crustosum and P. barbiger differ markedly from $P$. paucibarbiger in their much wider head due to the wide perifacial rim. Juvenile $P$. barbiger have no labial barbels and fewer chin barbels than adult specimens, so perhaps the few barbels in $P$. paucibarbiger may only be a characteristic of immature specimens of the species. No additional specimens with narrow head and perifacial rim have been reported in the eastern Pacific to date.

Etymology: From the Greek nesos meaning islander; to be treated as an adjective.

Habitat and associates: The new species was collected at Isla del Coco with otter trawls at depths between 110 and $180 \mathrm{~m}$. The species was not present in hauls made along the same transects at lesser depths. The sandy substratum is shown clearly in Figure 1. Typical demersal fishes found in the same hauls include Paralichthyidae, Triglidae, Anthiinae, Ophichthidae, Aulopidae, Ogcocephalidae and Malacanthidae.

\section{ACKNOWLEDGMENTS}

I am grateful to R. J. Lavenberg for organizing and taking part in the 1972 Janss Foundation cruises on the R/V Searcher to Costa Rica and Isla del Coco. Lavenberg recognized $P$. nesium as possibly new and obtained additional data for Peristedion from the Galápagos at CAS as well as the lectotypes of P. crustosum and barbiger. J. McCosker offered useful comments on an early version of the manuscript. Avi Klapfer kindly provided the photograph taken from a submersible. V. Garrison helped clarify several aspects of the manuscript.

Comparative material: Peristedion crustosum: MCZ 28704 (now USNM 153603) Lectotype designated by G. Miller. $111.5 \mathrm{~mm}$ SL, collected off Panama. LACM 20838, 1 (127.8mm), collected at Daphne Minor, Galápagos. UCR 492.014, 1 (110.0mm); UCR 501.001, 2 (109.7-119.5mm); UCR 1501.001, 13 (72.2101.3mm); UCR 1717.005, 7 (60.0-74.8mm); 
UCR 491.015, 7 (94-107mm ) collected off Pacific coast of Costa Rica. R. Feeney provided radiographs and Figures 2 and 3.

Peristedion barbiger: MCZ 28708, 106mm

SL; USNM 15360, 143mm. One chosen as lectotype by G. Miller. collected off Panama and Colombia. UCR 489.001, 7 (88.0-116.5mm); UCR 422.012, 4 (89.5-119.4mm); UCR 1730.003, 2 (88.5-90.0mm); UCR 1888.001, 4 (97.5-137.1mm) collected off Pacific coast of Costa Rica.

\section{RESUMEN}

Varias expediciones en años recientes a la Isla del Coco han aumentado el número total de especies de peces conocidas de la isla. Se han descrito varias de estas nuevas especies como endémicas (Bussing 1983, 1990, 1991a, 1991b, 1997). Durante la Expedición R/V Searcher de 1972 a Costa Rica, se hicieron varias recolectas con redes de arrastre alrededor de la isla. En cinco localidades, con profundidades entre 110 y $145 \mathrm{~m}$, se capturaron ejemplares de una nueva especie de Peristedion que se describe en este trabajo. Se incluye una clave para las cuatro especies del Pacífico oriental.

Palabras clave: Peristedion, nuevas especies insulares, Isla del Coco, Costa Rica, Galápagos.

\section{REFERENCES}

Bussing, W.A. 1983. A new tropical eastern Pacific labrid fish, Halichoeres discolor, endemic to Isla del Coco, Costa Rica. Rev. Biol. Trop. 31: 19-23.

Bussing, W.A. 1990. New species of gobiid fishes of the genera Lythrypnus, Elacatinus and Chriolepis from the eastern tropical Pacific. Rev. Biol. Trop. 38: 99-118.
Bussing, W.A. 1991a. A new genus and two new species of tripterygiid fishes from Costa Rica. Rev. Biol. Trop. 39: $77-85$.

Bussing, W.A. 1991b. A new species of eastern Pacific moray eel (Pisces: Muraenidae). Rev. Biol. Trop. 39: 97-102.

Bussing, W.A. 1997. Chriolepis atrimelum (Gobiidae) a new species of gobiid fish from Isla del Coco, Costa Rica. Rev. Biol. Trop. 45: 1547-1552.

Castro-Aguirre, J.L. \& F. García-Domínguez. 1984. Una nueva especie de Peristedion (Osteichthyes: Scorpaeniformes: Peristediidae) de la bahía de La Paz, Baja California Sur, México. An. Esc. Nac. Cienc. Biol. Méx. 28: 29-38.

Garman, S. 1899. The fishes. In Reports on an exploration off the west coasts of Mexico, Central and South America, and off the Galapagos Islands, in charge of Alexander Agassiz, by the U.S. Fish Commission steamer "Albatross," during 1891, Lieut. ...No. XXVI. Mem. Mus. Comp. Zool. Harvard Coll., 24: 1-431, Atlas: Pls. 1-85 + A-M.

Grove, S.G. \& R.J. Lavenberg. 1997. The fishes of the Galápagos Islands. Stanford University, Stanford, California, USA,

Miller, G.C. 1967. A new species of western Atlantic armored searobin, Peristedion greyae (Pisces: Peristediidae). Bull. Mar. Sci. 17: 16-41.

Miller, G.C. \& W.J. Richards. 2002. Peristediidae. Armoured searobins (armoured gurnards), 1278-1285 p. In K.E. Carpenter (ed.). The living marine resources of the Western Central Atlantic. FAO, Rome.

Richards, W.J. \& J.E. McCosker. 1998. A new species of the genus Bellator (Pisces: Triglidae), with comments on the trigloids of the Galápagos Islands. Proc. Riol. Soc. Wash. 11: 936-941.

Teague, G.W. 1961. The armored sea-robins of America. A revision of the American species of the family Peristediidae. An. Mus. Hist. Nat. Montevideo Ser. 7: 1-27. 